\title{
THE CZECH REPUBLIC ATMOSPHERIC PROTECTION IN THE CONTEXT OF TAX LEGISLATION
}

\author{
M. ČERNÍKOVÁ \\ Faculty of Economics, Technical University of Liberec, Czech Republic.
}

\begin{abstract}
In the Czech Republic, the issues concerning the environment since the 90s of the last century have been discussed. At that time, the political system as well as an attitude to the environmental questions was different. Since then, atmospheric protection in the Czech Republic has significantly improved. Current status and positive progress of the environment in the context of a sustainable development is guaranteed by the EU legislation also in the Czech Republic. The paper discusses efficient environmental tools used in the Czech Republic, their strength and weaknesses. These tools affect the interaction between manufacturing corporations and the major components of the environment, especially air. In this paper, the system of atmospheric protection in the Czech Republic and instruments which are efficient and well applicable in the corporate environment are analyzed. The paper pays main attention to economic tools, especially the potential of a tax system. The Czech Republic tax legislation has recently undergone a considerable change in the field of environmental protection, especially with regard to the income tax. In 2011, many tax exemptions and benefits that were related to the implementation of environmental systems in practice were cancelled. A case study is being realized to explore how the amendment of the legislation, especially the income tax act, affected the decision-making of economic subjects with regard to environmental aspects of their own business activities in the field of alternative sources of energy.
\end{abstract}

Keywords: Alternative energy sources, efficiency of enterprises, environmental instruments, environmental policy, photovoltaic power stations, voluntary activities of enterprises, voluntary approaches.

\section{INTRODUCTION}

The issues of atmospheric protection are always connected with activities of economic entities that have an influence on the quality of the environment. The extent of not only local, regional but also national and international negative impact on the environment demonstrates that we simply cannot rely on market mechanisms, hoping they will regulate such an impact on the environment automatically. A deficit in the functioning of market mechanisms is caused by a collective ownership of environmental goods that are globally used by the whole community [1]. In the context of requirements on a sustainable development of a civilized community, it is necessary to systematically control and manage interactions between the economic development and the state of the environment.

In activities of economic entities, especially in developed industrial areas, a market balance has been impaired due to various reasons, which leads to the occurrence of negative externalities relating to atmospheric pollution. The conflict between the interests of the polluter and concerns of the company results in a necessity for the management of the conflict using various environmental tools of atmospheric protection.

A mix of these tools implements state into a business environment within the framework of state environmental policy, thus affecting the behavior of individual economic entity. Currently, tax legislation represents an important economic tool for the environmental protection. In the Czech Republic, there are many stipulations in the tax legislation supporting the environmental-focused activities at the level of enterprises. Considering historically the most significant sources of air pollution in the Czech Republic - thermal power plants - environmental activities supported by tax legislation are especially aimed at making the best of the potential of alternative energy sources. In this paper, a 
case study whose main goal is to explore the possibilities of tax optimization of these energy sources within the framework of business activities in consideration of the current tax legislation of the Czech Republic is described.

This paper was prepared using a wide multidisciplinary approach including various procedures, methodologies, research into relevant legislation and preparation of theoretical pieces of research. The data were collected from articles published in various vocational magazines as well as official websites and thoroughly analyzed.

\section{ATMOSPHERIC QUALITY PROTECTION IN THE CZECH REPUBLIC}

Relation to the environment has been developing for a relatively long time in the Czech Republic. At the end of the 80s the Czech Republic was facing not only problems related to the change of a political system, but also a big devastation of the environment as a result of a complete absence of ecological policy and other aspects in a socialist government decision-making. For many decades the main priority of "building the system of socialism" remained quantitative growth of mainly the primary sector and heavy industry without any respect to the environmental protection requirements; due to this attitude, the Czech Republic was one of the most polluted regions in Europe with the highest emission of a wide range of pollutants in the air. The change of a political system in 1990 brought about a significant improvement of air quality in the Czech Republic. Figure 1 shows the development of air pollution by major pollutants in the Czech Republic within the past 20 years [2].

Some of the main reasons for more satisfactory air condition in the Czech Republic were: the decrease of industrial activities in the first few years after November 1989, introduction of key laws related to the environmental protection, finding relevant environmental institutions, and creating effective system of environmental protection. The air pollution by sulfur oxides was significantly reduced. Companies emitting these pollutants to the air were forced to take measures in a relatively short time to meet strict limits, which in some cases led to cuts in production or halting of production altogether. Other pollutants that did not reach such high levels are still present in the air and their reduction is problematic for many reasons not only in the Czech Republic, but also in Europe - the

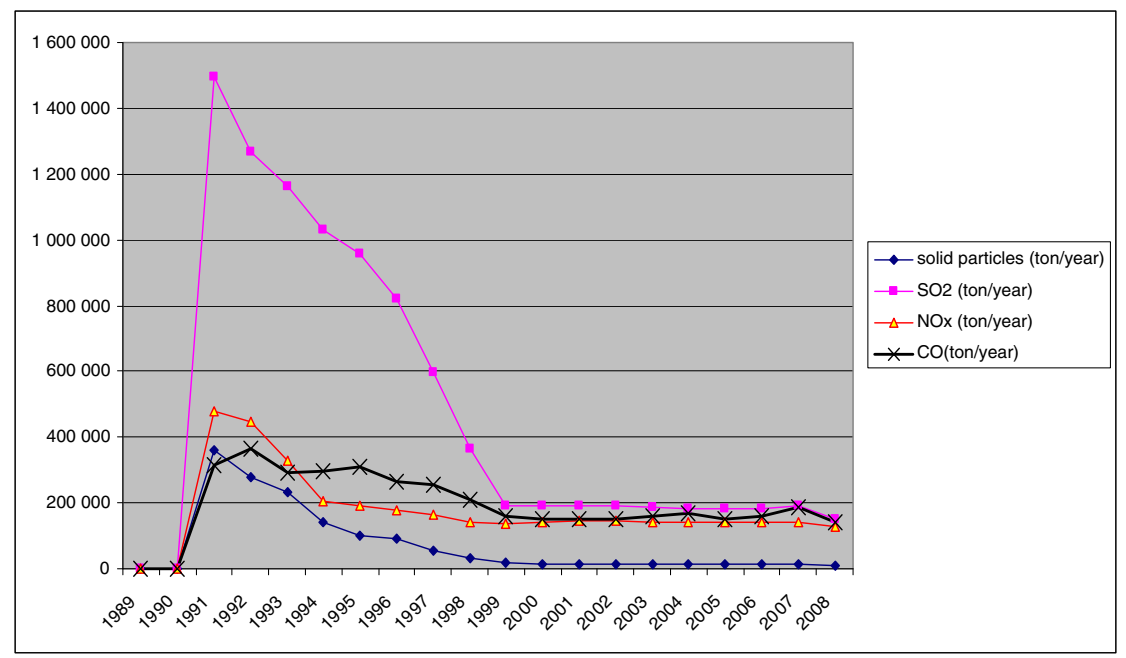

Figure 1: Development of air pollution by major pollutants in the Czech Republic. Source: Author's submission, the Czech Statistical Office [3]. 
situation of air pollution has been steady for the last few years. A number of measures have been taken leading to a higher atmospheric protection since the Czech Republic joined the EU. A present state and a satisfactory development of atmospheric protection in the Czech Republic is guaranteed by the need to conform to the European Union legislation.

\section{ENVIRONMENTAL TOOLS OF ATMOSPHERIC PROTECTION}

In the past few decades, multiple environmental tools in relation to the quality of air have been implemented in the Czech Republic with different effectiveness. These tools may be divided into several groups.

\subsection{Normative (administrative) tools}

Normative tools of the environmental policy are based on a compulsory authority of state administration bodies. Such tools especially cover:

- directives (orders and prohibitions),

- limits (material, time),

- rules and technical standards.

Regulation system of atmospheric protection is based on legislatively supported administrative measures intended to affect behavior of polluters, their control and imposition of possible sanctions (fines, penalties) in case of non-performance of legislative requirements. These tools are environmentally effective; however, they are accompanied by quite a lot of deficiencies [4]. Direct regulation requires an extensive administration and subsequent inspection. This means a risk of inefficient bureaucratic management, corruption and needless expenses. Despite many disadvantages and difficulties, normative tools have been so far the most widely used tools in the field of atmospheric protection. Direct regulation is especially effective in areas where the goals must be achieved immediately. The current requirements for environmental maturity of economic subjects, however, require new attitudes that offer multiple options and promote voluntary approaches.

\subsection{Economic tools}

Economic tools of atmospheric protection are based on the indirect factors affecting the behavior of economic subjects causing harm to the environment [5]. Each economic subject (companies, households) may decide whether it is more advantageous to expend some money on mitigation or elimination of impacts on the environment or to damage the environment and pay for it in the form of fees and taxes. New environmental protection system that has been developing in the Czech Republic since 1990 makes use of various economic tools for environmental protection. One of the most significant economic tools is the fees for atmospheric protection; in recent years this issue has also been more increasingly considered in the government's tax system.

\subsubsection{Fees designated for the atmospheric protection}

The most widespread form of economic tools of atmospheric protection in the Czech Republic are the tools of the so-called negative stimulation, especially the fees designated for the atmospheric protection. The amount of such fees usually depends on the quantity and concentration of the emissions released to the air. The fees are considered to be environmental costs of companies - polluters. The fee should motivate the companies - polluters - to adopt such measures that will contribute to 
atmospheric protection. The amount of fee should be based on the costs for the elimination of damage, so that no economic advantage is given to those organizations that pay lower amount than the potential environmental damage. The fee should serve as a tool for giving precedence to those companies that act responsibly and protect the atmosphere. Their market position should then be stronger [6]. Emission allowances are also a very important economic tool in the Czech Republic [7].

\subsubsection{Tax system in the Czech Republic}

Another economic tool that contributes to atmospheric protection is the Czech Republic tax system, with many more standard functions (allocation, distribution, fiscal). In this way, functions of the tax system are extended; thus, the tax system not only acts as a fiscal tool that brings certain tax revenues into public budgets, but also the tool of the state environmental policy aimed at the limitation of air quality deterioration [8].

As for the current tax legislation of the Czech Republic, environmental aspects are incorporated in a direct taxes section in the form of multiple tax allowances, disallowances or exemptions facilitating the environmental protection process. The crux of the environmental regulation is currently moving mainly to the area of indirect taxes [9]. Indirect taxes have an imminent effect on the price of the goods they are imposed on; thus, they can greener production with lower emissions.

The move to indirect taxes should be - in accordance with the principle of tax neutrality - compensated by reduction of other taxes. In the end, this should contribute to the growth of national economy. Reduction of labor costs should help to maintain competitiveness of our economy. At the same time, it should represent a kind of stimulus attracting foreign investors. In the EU countries this conception (so-called ecological tax reform) has been discussed for many years as one of the potential approaches to improvement of the quality of environment and also to lowering air emissions.

The ecological tax reform should be implemented in the Czech Republic in three successive phases within the period 2007-2017. Just as in other EU countries also in the Czech Republic the reform should be based on the principle of tax neutrality, i.e. revenues should be used for the reduction of labor costs.

The first phase of the ecological tax reform was completed by the introduction of the Council Directive 2003/96/EC into the Czech Republic legislation. Since 2008 the existing tax system of the Czech Republic has been amended by taxation of energy products and electricity through the Act No. 261/2007 Coll. The subject of taxation covers natural gas, solid fuels, and electricity. A reduction of labor costs in 2008 was realized by abatement of income tax of both physical and legal entities. Quite extensive amendment to the income tax legislation changed the system for determination of tax base and tax allowances, and also lowered the social insurance rates.

The second phase of the ecological tax reform should be realized within the period 2010-2013. During this phase, tax rates and allowances for solid fuels and natural gas should be changed. The main goal is to revise the existing fees and other tools with an option to transform the selected environmental fees to environmental taxes. Special attention should be paid to the traffic, as one of the main air polluters, and also to administration of environmental taxes or transformed fees, especially to the principle of tax neutrality [10].

The third phase is scheduled to the period 2014-2017. In general, this phase should correspond with the amended EU directives. Its conception should be based on the analysis of the two previous phases, assessment of all their effects and impacts, and it might also be based on a political situation in the Czech Republic in the forthcoming decade [11].

So far, the economic tools do not represent the core area of atmospheric protection in the Czech Republic. In practice, there is still a significant majority of normative tools, while economic tools are rather perceived as a certain supplement to the normative ones. When creating specific atmospheric 
protection policies, both groups of tools are not considered equal. The main reason for the existence of economic tools is mainly their fiscal effect [12].

\subsection{Voluntary environmental activities by organizations}

With the requirement for a sustainable development and constantly increasing environmental awareness, new voluntary approaches to atmospheric protection have been emerging since the ' 80 s of the last century. Voluntary activities support the strategy of preventive approaches realized by companies beyond the scope of a statutory legislation framework with the aim to mitigate negative impacts of their activities on the environment, to consolidate their market position, to improve their competitiveness as well as the company image [13]. This is a significant turnover in the perception of atmospheric protection. Small effect of sanctions or various subsequent measures leads to a deflection from these traditional tools and inclination to voluntary preventive actions that are introduced into decision-making processes at the company level, affecting each and every activity of the company that is related to the environment. Voluntary activities are consolidated at the international level and a wide range of tools is also implemented by business entities in the Czech Republic [14].

\section{ALTERNATIVE SOURCES OF ENERGY FOR ATMOSPHERIC PROTECTION}

The Czech Republic together with other European countries looks for new directions in the field of environmental protection and particularly the air quality improvement. Despite a plenty of steps that have been taken in the past to improve the quality of air, such as desulphurization of operations and facilities representing a real burden for the environment, termination of activity of the most severe polluters, there are many problems and issues that still persist. One of the ways how to deal with the issue of air quality is to look for alternative (renewable) sources of energy and making the best of their potential in the business environment [15].

Production of energy from renewable sources has been strongly supported by the European Union in the recent years. The Czech Republic - within the framework of its EU membership - committed itself to produce $8 \%$ of all energies consumed from renewable sources until the end of 2010 . The current goal is to produce $20 \%$ of electricity from renewable energy sources by 2020 . In the whole European Union as well as in the Czech Republic, the number of newly connected photovoltaic power plants, as the most popular tool for the use of solar radiation as a renewable source of energy, rapidly increased in the recent years. This significant growth is clearly shown by graph in Fig. 2 .

Nowadays the use of solar energy is quite frequently discussed topic, especially with regard to the price of electricity produced by solar power plants and potential support of this production by the government. The fact that production of energy from any renewable source whatsoever is never completely environmentally friendly and always represents a certain burden for the environment is also quite considerable.

Pursuant to the Czech Act No. 100/2001 Coll., on Environment, renewable sources of energy are defined as follows: "Renewable natural resources, while being consumed, have a capability of partial or complete renewal, either in natural way or with a contribution by human" [16]. The most widely known renewable sources are solar radiation, wind and water energy, and biomass. Further, the energy of tide and geothermal energies can be included in the renewable energy sources.

Making use of the potential offered by renewable energy sources brings - besides environmental effects - several obligations associated with the national legislation. Czech enterprises (just as in other EU countries) focused their attention especially on the use of solar energy (see Fig. 3).

Production of electricity by the means of photovoltaic power plants is considered to be an undertaking on basis other than the standard trading license, and is subject to special regulations. This 


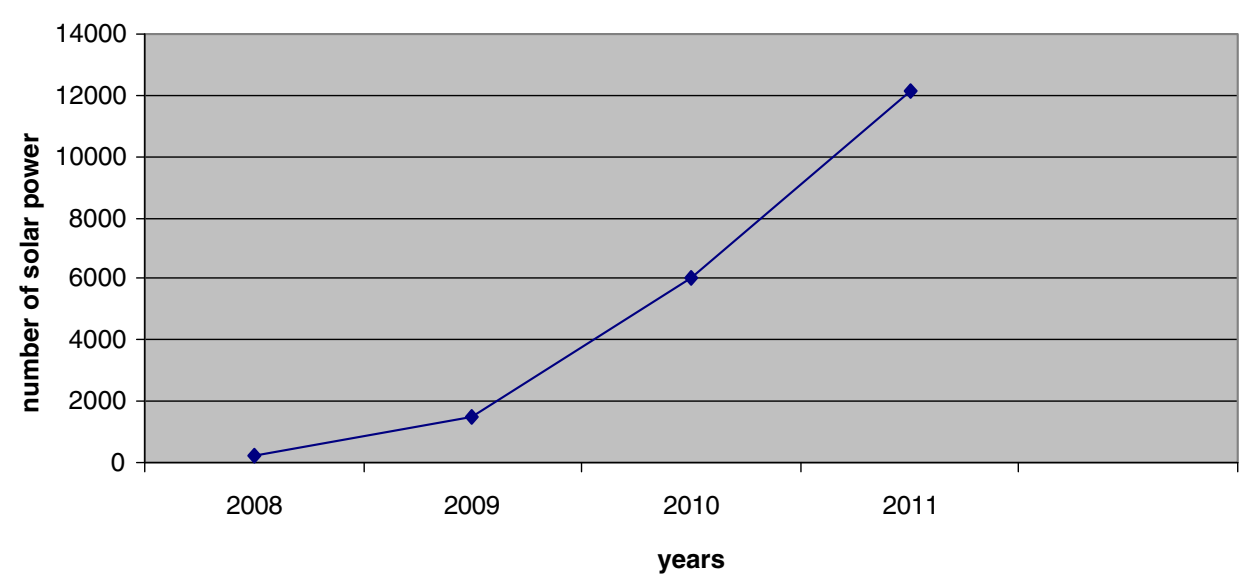

Figure 2: Development of solar power plants in the Czech Republic. Source: Author's own work.

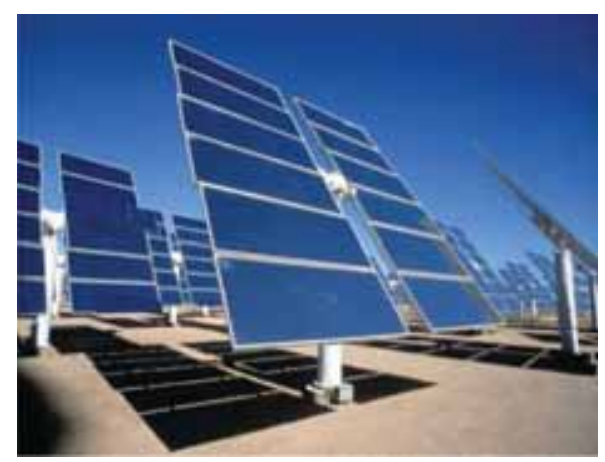

Figure 3: Photovoltaic power plant. Source: www. Nazeleno.cz.

business activity is governed by legislation that has undergone significant changes in the Czech Republic during the recent years and it well reflects the attitude of the society to this issue.

\section{TAX LEGISLATION APPLICABLE TO ALTERNATIVE ENERGY PRODUCTION}

Taxes in its historical development have always performed many functions that reflected current social needs. In current tax systems of developed countries, there are a number of provisions promoting environmental protection. Collected taxes represent substantially higher costs for those subjects harming the environment by emissions; in such a way the environmental problems are potentially addressed [17]. This is especially a legislative provision in the area of excise taxes, and also in the field of the environmental taxes that have been implemented in tax systems in recent years. In connection with a growing support of the use of alternative energy, tax systems have also undergone significant modifications in the field of direct taxation. As a part of national policy to fight against a climate change and energy independence, tax incentives supporting the production and the use of renewable energy sources and energy efficiency are implemented in the provisions of tax legislation [18]. These mechanisms can play an important role in achieving the set goals leading to greater use of alternative energy sources as well as reduction of energetic demand and creation of a sustainable energy platform. 
For a business-related activity focusing on the production of alternative energy sources, the most significant legislative change is incorporated in particular provisions of the Income Tax Act and in the regulations regulating social security and health insurance.

\subsection{Provisions of the income tax act in the environment of the Czech Republic}

Incomes from the operation of the equipment producing alternative energy sources (namely, photovoltaic power plants) are - within the framework of the Czech Republic legislation - classified as incomes from business and other self-employment activities.

A partial tax base of income tax is represented by incomes from business and other self-employment activities reduced by expenses incurred on achieving, securing and maintaining such incomes. A tax payer may either claim expenses in their actual amount (documented amounts) or claim flat-rate expenses. The flat-rate expenses cover all expenses associated with the business, including, but not limited to depreciations and credit interests. In 2011, the flat-rate expenses represented $40 \%$ of incomes from operation of a photovoltaic power plant. Should the actual expenses be higher than $40 \%$ of the incomes achieved, it would be more beneficial to claim the actual expenses instead of the flat-rate expenses. Legal entities are not allowed to claim the flat-rate expenses. As for legal entities, the tax base is calculated from the determined economic result for the previous period, adjusted by expenses and items not included in the tax base; on the other hand, it is increased by costs and expenses that cannot be claimed as expenses incurred on achieving, securing and maintaining of incomes. Such a tax base is further reduced by other deductions allowed and rounded down to whole thousands. After these adjustments the tax base shall be subject to $19 \%$ taxation (tax rate valid for 2011).

Tax legislation that stipulates conditions for business activities in the field of alternative energy sources went through significant changes in 2010 and 2011. Until 2010, the income tax act defined the full exemption from the income tax in the calendar year of photovoltaic power plant operation commencement and within the next five years. During such period of exemption, the tax payer could not claim expenses for achievement of the incomes as tax-deductible expenses of the income tax. In accordance with relevant provisions of the income tax act, the payer could refuse to utilize the exemption. To do so, it would have to notify the tax administrator within the period for the submission of tax return for the taxation period the power plant operation commenced in. Payers who decided for the exemption did not cover (during the exemption period) incomes from photovoltaic power plant in their tax returns.

The amendment of the income tax act for the year 2011 cancelled the possibility of exemption of incomes gained by operation of ecological energy sources (i.e. photovoltaic power plants) from income tax. This change is valid both for physical persons and legal entities by means of specific legislative provisions [19].

The income tax act also stipulates specific conditions for depreciation of solar systems. According to the applicable regulations, photovoltaic power plants represent a tangible assets used for the production of electricity from solar radiation (solar panels, converters and distributors). Since 2011 the whole solar system has been depreciated for the period of 240 months up to $100 \%$ of its acquisition price or increased acquisition price (due to technical appreciation of the assets).

\subsection{Provisions of legislation on health insurance and social security}

A solar power plant operator is characterized as an undertaker subject to special regulations, becoming a payer of health insurance pursuant to valid legislation applicable to the field of the public health insurance scheme. The insured party shall be obliged to report this fact no later than 8 days 
following the commencement of business activities to the relevant health insurance company, i.e. the company receiving the health insurance premium.

In accordance with the amendment of legislation adopted in 2010 in the field of health insurance and social security, a basis for assessment of self-employed persons (undertakers) shall be $50 \%$ of the incomes from business and other self-employment activities after deduction of expenses incurred on achieving, securing and maintaining the incomes. With regard to partners of public limited companies (partnerships) and unlimited (general) partners in special limited partnerships, the incomes from the self-employment activities, reduced by the expenses incurred on the achieving, securing and maintaining the incomes, for the purposes of health insurance, are represented by a tax base determined on the basis of incomes from these activities. The Act No. 458/2000 Coll. (on Business Conditions and Public Administration in the Energy Sectors and on Amendment to Other Law - the "Energy Act" as amended) sets the obligation for photovoltaic power plant operators to keep accounting books within the framework of financial accountancy system. However, since 2011 the tax records pursuant to the income tax act have been considered as sufficient for the registration of incomes and expenses. Despite the fact that the logics of the act presumed that during the period of exemption of incomes from the income tax (i.e. no tax base is generated) the business entities will not be obliged to pay the insurance, the Ministry of Labor and Social Affairs refused this interpretation and the insurance had to be paid. Starting from 2011, the exemption of incomes of ecological entities from income tax was cancelled, which meant that the doubts about the obligation to pay the insurance disappeared.

Health insurance is $13.5 \%$ of the assessment base. If the electricity producer is simultaneously an employer and the self-employment is a secondary source of income, the producer is not obliged to pay (pursuant to the applicable legislation) advance payments for the insurance but shall pay the whole insurance within 8 days following the submission of tax return for the previous calendar year.

Within the scope of the amendment of social security legislation, the photovoltaic power plant operator shall be obliged to notify the relevant district administration of social security (Social Security Administrator) of the commencement of its business activity within the first 8 days in the next calendar month, whereas the payer becomes an official social security payer (insured party) as of the same date. The operator shall further notify the Social Security Administrator whether the operation of solar power plant is its main or secondary activity. Self-employment is considered as secondary activity if the self-employed person was regularly employed in the same calendar year, was entitled to receive disability pension or was entitled to receive parental allowance or maternity allowance. Should it be considered as a secondary activity and the total incomes from the operation do not exceed the amount of CZK 59,373.00 (€ 2,400.00) per year (in 2011), the operator is not obliged to be involved in the social security scheme.

A basis for the calculation of social security is the amount determined by the payer himself, but not less than $50 \%$ of tax base. The current insurance rate is $29.2 \%$ for self-employed persons. The legislation further determines minimum monthly advance payments the undertaker must pay for administration of social security and health insurance. In 2011, the minimum monthly advance payment for health insurance was CZK 1,670 (€ 67.00) per month. With regard to secondary activity, no advance payments have to be paid - only the actual amount of insurance rate. As for social security, the minimum advance payment for the main activity is CZK 1,731 (€ 70.00) per month and CZK 693.00 (€ 28.00) for a secondary activity [20].

As the production of electricity from photovoltaic power plants (as well as all the other renewable sources of energy) is classified as undertaking pursuant to special regulations, the power plant owner must consider these obligations and specific conditions while evaluating economic efficiency of the power plant operation. The payments associated with health insurance, social security and income tax must be considered in the analysis of expenses related to the power plant operation. 


\section{MODEL STUDY: TAX OPTIMIZATION OF ALTERNATIVE ENERGY SOURCE BUSINESS IN THE CZECH REPUBLIC TAX ENVIRONMENT}

In accordance with the Czech Republic legislation the photovoltaic power plant operator is defined as an undertaker with certain obligations in the field of income tax payments as well as reimbursements of health insurance and social security.

In consideration of these basic facts a tax optimization strategy is developed for incomes from the operation of ecological facilities. Upon putting the photovoltaic power plant into operation, a selection of the most appropriate tax optimization may significantly affect the tax base, final tax liability as well as annual amount of payments for mandatory insurance (health insurance and social security scheme). These legislative liabilities are also considered as a factor significantly affecting the success of the business process.

For the case study of tax optimization regarding the start-up and operation of alternative source of energy a photovoltaic power plant with output of $5 \mathrm{~kW}$ was selected. During the service life of the power plant we expect (for the purposes of the model study) a constant output from the power plant. The power plant produces $6,000 \mathrm{kWh}$ of electrical energy on annual basis. For the purposes of the case study, we assume that the owner sells the whole production of electrical energy and - within the framework of buy-back prices - gets CZK 12.50 (resp. € 0.50) per $1 \mathrm{kWh}$ sold. Total income from the sale of electricity is calculated to be CZK 75,000.00 per year $(€ 3,000.00)$. Acquisition costs of the power plant are defined to be CZK 560,000.00 (€ 22,400.00). The annual operating expenses were estimated to CZK 6,000.00 (€ 240.00). As this is a relatively small power plant, it is assumed that the owner - physical person - has this income as a secondary income. Therefore, the health insurance is paid according to the actual assessment base, and social security is not paid at all. In case of the low assessment base, the owner is not obliged to pay it. An important part of tax optimization of potential incomes is the resolution to include photovoltaic power plants (classified as long-term tangible assets) into the system of depreciations. Depreciations calculated pursuant to the relevant regulations and rules may be included by the power plant owner into actual expenses that may be deduced from incomes in connection with the calculation of income tax [21]. For the model calculation the tax depreciations were assumed to be identical with accounting depreciations. A method of equal depreciation was applied in this case. Tax optimization will be explored during the initial 10 years of power plant operation.

\subsection{Tax optimization under legislative conditions of 2010}

Until the end of 2010 the taxation of incomes from operation of photovoltaic power plants was not strictly regulated and the legislation allowed for various approaches to this issue. According to tax legislation valid in 2010, photovoltaic power plants were depreciated in group 3 with a service life (usable life) of 10 years.

There were three basic options for an enterpriser in the context of the valid legislation:

A) to claim flat-rate expenses ( $40 \%$ of incomes generated by the power plant) during power plant operation for the entire period;

B) to claim actual expenses (depreciations and other operational costs and expenses) during power plant operation for the entire period;

C) to claim full exemption from taxation in the first year of the power plant launch and during the subsequent five years (with a possibility to switch to claiming of actual expenses later on). 
The following Table 1 shows a tax burden of a power plant owner in 2010 for all variants suggested.

As obvious from the table, the most interesting (from the taxation point of view) seems to be Variant $\mathrm{C}$ which is based on the full exemption of incomes from taxation in the year when the solar system is put into operation and during the subsequent five years. Social security does not need to be paid as the limit for these payments is not fulfilled; however, the health insurance must be paid - at least at the minimum rate.

Analysis of the total impact of tax burden on particular variants can be done with the following figure. To allow for comparison of results, the calculations covered in the figure are based on legislative conditions of the year 2010 for the whole period of solar facility operation (i.e. for the period of 10 years).

From the Fig. 4 it is obvious that under Variant A (i.e. claiming of flat-rate expenses $-40 \%$ of incomes) the tax liability is standard during the whole period of photovoltaic power plant operation,

Table 1: Overview of taxes and health insurance/social security paid under particular variants in 2010 (in Euro currency).

\begin{tabular}{lrrr}
\hline Economic categories $(€)$ & Variant A & Variant B & Variant C \\
\hline Operating incomes & 3000 & 3000 & 3000 \\
Operating costs & 1200 & 240 & 0 \\
Tax depreciations & 0 & 1232 & 0 \\
Income tax base & 1800 & 1528 & 0 \\
Tax liability & 270 & 230 & 0 \\
Social security & 0 & 0 & 0 \\
Health insurance & 122 & 15 & 64 \\
Paid in total & 392 & 245 & 64 \\
\hline
\end{tabular}

Source: Author's own work.

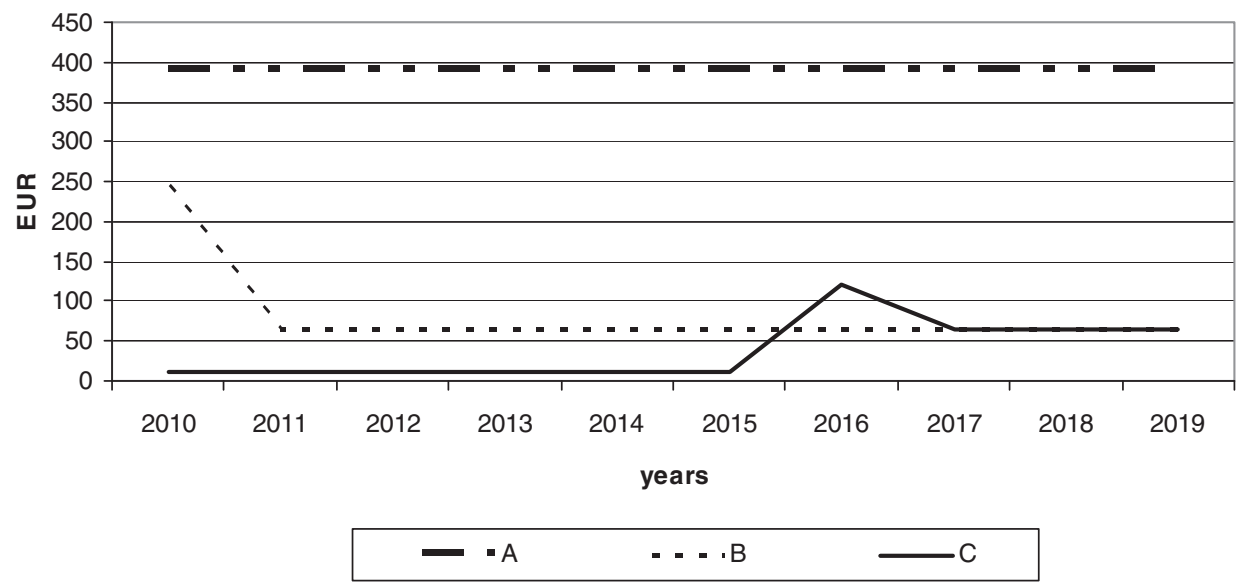

Figure 4: General development of tax burden for particular variants of tax optimization during the period of 10 years (subject to conditions valid in 2010). Source: Author's own work. 
i.e. during 10-year period. Should the actual expenses be claimed during the whole period of photovoltaic power plant operation (Variant B), there will be higher payment in the first year of operation as it is not possible to deduce the whole tax depreciation from the tax base. In the next years the tax liability is evenly reduced by the full amount of depreciations. The variant that combines exemption from tax, claiming of actual expenses (Variant C), is the most optimal one during the whole operation of the power plant as during the first six years the full exemption is enforced and then actual expenses are claimed, increased by depreciations. However, this is only a model reflection as we work with simplified presumptions that the legislative conditions will be constant all throughout the operation period of the photovoltaic power plant.

\subsection{Tax optimization under legislative conditions of 2011}

The amendment of the income tax act in 2011 cancelled the exemption of incomes of ecological facilities from income tax, which means a significant change of tax optimization options. A solar power plant operator may - during the whole period of power plant operation - claim expenses either in their actual amount or as flat-rate expenses. Theoretically, a combination of both these approaches may be applied. Transition to the enforcement of flat-rate expenses comes at the time when actually incurred expenses cease to cover the depreciations. Because the amendment of the income tax act in 2011 also changed the conditions for depreciations (photovoltaic power plants solar panels, converter and distributors are subject to even depreciations for the period of 20 years up to $100 \%$ of the acquisition price), this variant seems to be practically uninteresting as after 20 years of operation the equipment is clearly beyond the real service life span.

The following Table 2 compares two variants of potential tax optimization:

A) enforcement of flat-rate expenses during the whole period of equipment operation;

B) enforcement of actual expenses (depreciations and other operating costs).

From the data in the table it is obvious that the cancellation of the exemption of solar power plants' incomes from income tax considerably reduced the space for tax optimization compared with 2010. Under these conditions the more expedient seems to be Variant B assuming the claiming

Table 2: Overview of taxes and health insurance/social security paid under particular variants in 2011 (in Euro currency).

\begin{tabular}{lcc}
\hline Economic categories $(€)$ & Variant A & Variant B \\
\hline Operating incomes & 3000 & 3000 \\
Operating costs & 1200 & 240 \\
Tax depreciations & 0 & 482 \\
Income tax base & 1800 & 2278 \\
Tax liability & 270 & 342 \\
Social security & 0 & 0 \\
Health insurance & 122 & 23 \\
Paid in total & 392 & 365 \\
\hline
\end{tabular}

Source: Author's own work. 


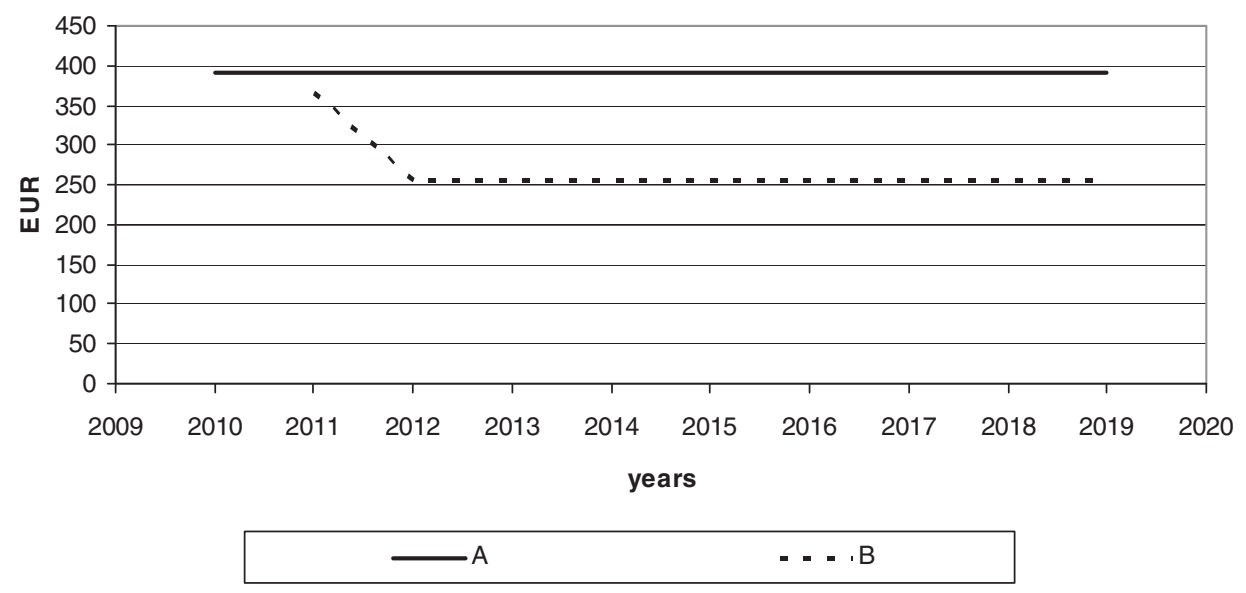

Figure 5: Development of tax burden for particular variants of tax optimization during the period of 10 years (under conditions of the year 2011). Source: Author's own work.

of actual expenses. This variant is more beneficial even from the long-term point of view, as shown in Fig. 5.

From the graph it is obvious that claiming of actual expenses covering depreciations during the whole period of service life (according to the income tax act), i.e. Variant B, means more beneficial tax optimization than with the use of flat-rate expenses (40\% of incomes) in Variant A. In the first year of the variant of actual expenses, the payments are higher, as it is not possible to claim the whole depreciation, but only a part of it. In the next years, until the full depreciation of the assets, the expenses are identical. This is, however, an illustrative model only as it is assumed that the economical parameters of the year 2011 remain unchanged. In reality, we can of course count with the change of tax rates as well as different conditions of social security and health insurance.

From the case study above it is clear that the Czech Republic has adopted several measures aimed at the limitation of support of the alternative sources of energy and this trend seems to continue. One of the reasons of this approach is a huge increase of business activities in the field of alternative energy sources, dealing with fiscal issues and looking for sources of financing the public budgets.

\section{CONCLUSION}

The conception of a sustainable development accents together with social and economic issues the importance of environmental awareness. Protection of all segments of environment, especially atmospheric protection, is an integral part of all environmental strategies developed at the level of international institutes and communities, but also affects policies of individual countries and the way of living of each subject of our community, i.e. business entities and all human beings (individuals) in general.

In recent decades, the Czech Republic, as a legitimate member of the European Union, has come with several initiatives that improved - in terms of quality - our relation to critical environmental issues, especially the protection of air. Within the framework of our state environmental policy the state authorities develop and implement a mix of environmental tools in the economic environment the purpose of which is to improve the quality of all segments of environment, including the quality of air. Administrative tools representing a complex of directions and regulations are largely covered by this mix of tools. Recently, we have also witnessed an increasing importance of economic tools which are mainly represented by fees and charges collected from economic subjects involved in air 
pollution as well as pollution of other segments of environment. The Czech Republic tax system is relatively a new tool for the solution of environmental problems. However, actions and measures implemented by individual business entities also play irreplaceable role in environmental protection. The companies show proactive approach to environmental protection, not only by taking care of their own environmental profile, but also contributing to increased awareness of environmental issues within the whole community by means of voluntary tools and measures.

One of the ways how to reduce air pollution resulting from business activities is to make use of cleaner alternative sources of electrical energy. Recently the amount of investments in alternative sources of energy, especially in sources that make use of solar radiation, has been growing fast in the Czech Republic. For the case study a special attention is paid to legislative conditions for the use of alternative sources of energy within the scope of business activities. This matter is not only covered in and governed by accounting and tax regulations, but also the acts applicable in the field of health insurance and social security. In numerous amendments of tax legislation in the past three years, the support of government, originally aimed at the development of environmentally-friendly facilities for production of energy, has been considerably limited and also the tax support of these facilities is much lower than that in the past. In the context of the case study focused on tax optimization of photovoltaic power plant operation, the legislative conditions of the year 2010 are considered; in this year multiple approaches to taxation of these activities were available and the legislative environment was quite welcoming for this kind of business. As a contrast to the year 2010, we present the analogical calculations and assumptions for the year 2011. This year should - based on amendments of the applicable legislation - considerably limit the options of tax optimization associated with operation of alternative sources of energy. The change of approach of the Czech Republic to the matter of atmospheric protection is a consequence of multiple points of view. On the one hand, there is a chance to completely eliminate our dependence on standard sources of energy representing a real burden on quality of air (air pollution mainly caused by carbon oxides but also dust particles), but on the other hand, the Czech Republic faces fiscal problems and looks for financial resources to feed public budgets. The question is whether the Czech Republic government prefers higher tax revenue or cleaner atmosphere.

Recently, the international political scene in developed and advanced countries as well as general public have had to deal with several crucial problems and topics. The problems related to economic crisis of developed countries, monetary policy of the European Union as well as focal points of conflicts scattered all around the world are mainly accented.

In the context of recent development, the environmental questions may be seen as topics that do not require an urgent attention or preferential solution. However, the leading politicians emphasize that the developed countries should not only focus on financial crisis, but should deal with long-term matters as well, such as sustainability and improvement of efficiency of natural resources utilization. That is to say, although financial crisis remains the main topic, environmental issues should not be neglected. Both these phenomena are interrelated - natural resources are almost depleted. Only economics that will be able to utilize lower energy and raw material inputs, which means those that will be able to consider environmental aspects in their business activities, might be more competitive and able to achieve economic growth.

\section{ACKNOWLEDGMENTS}

This paper was written as one of the outputs of the research project "Environmental Tax Reform in the Context of Environmental Policy of the Czech Republic", which was implemented at the Faculty of Economics of Technical University of Liberec in 2011 with the financial support from the Technical University in the competition supporting specific projects of academic research (student grant competition). 


\section{REFERENCES}

[1] Villlacampa, Y. \& Brebbia, C.A. (eds), Ecosystems and Sustainable Development VIII, WIT Press: Ashurts, 2011.

[2] Reports on the environment in individual years. The Ministry of Environment, Online. www. mzp.cz.

[3] State of the environment in individual years. Czech Statistical Office, Online. www.czso.cz/ csu/edicniplan.nsf.

[4] Wiener, J., Global environmental regulation: instrument choice in legal context. Yale Law Journal, 108, p. 983, 1999. doi: http://dx.doi.org/10.2307/797394

[5] Endres, A., Umweltökonomie: Arbeits - und Übungsbuch, Kohlhammer: Stuttgart, pp. 120-150, 2007.

[6] Repetto, R., Pure Profit: The Financial Implications of Environmental Performance, World Resources Institute: Washington, D.C, pp. 40-50, 2000.

[7] Malikova, O. \& Horak, J., Environmentally related impacts on financial reporting: the case of pollution permits in Czech legislative conditions. WIT Transactions on Ecology and the Environment, 147, pp. 433-442, 2011.

[8] Scasny, M., Administrative and induced costs of fees for air pollution and energy taxes. Proc. of the 1st Int. Conf. On Modelling of impacts of environmental regulations, ed. M. Scasny, The Center for Environmental Issues, Charles University: Praha, pp. 9- 1, 2010.

[9] Bosquet, B., Environmental tax reform: does it work? Ecological Economics, 1(34), pp. 19-32, 2000. doi: http://dx.doi.org/10.1016/S0921-8009(00)00173-7

[10] Malikova, O. \& Cerníková, M., Environmental tools of atmospheric protection in the Czech Republic. WIT Transactions on Ecology and the Environment, 147, pp. 423-433, 2012.

[11] Principals and schedule of environmental tax reform. The Ministry of Environment of the CR, Online. www.mzp.cz.

[12] Poterba, J., Tax Policy and the Economy, MIT Press: Massachusetts, pp. 150-182, 2006.

[13] Burrit, R. \& Schaltegger, S. An Introduction to Corporate Environmental Management Striving for Sustainability, Greenleaf Publishing: Sheffield, pp. 58-72, 2003.

[14] Paton, B., Voluntary environmental initiatives and sustainable industry. Business Strategy and the Environment, 9(5), pp. 328-338, 2000. doi: http://dx.doi.org/10.1002/10990836(200009/10)9:5<328::AID-BSE259>3.0.CO;2-Z

[15] Eidt, B.D., Global energy management system. Proc. of the Carbon Management Technology Conference 2012, Society of Petroleum Engineers: Orlando, pp. 403-411, 2012.

[16] Dvorak, P., Environmental Laws, Sevt: Praha, 1993.

[17] Goulder, L.H., Parry, I.W.H., Williams, R.C. \& Burtraw, D., The cost-effectiveness of alternative instruments for environmental protection in a second best setting. Journal of Public Economics, 72(3), pp. 329-360, 1999. doi: http://dx.doi.org/10.1016/S0047-2727(98)00109-1

[18] Garciano, J.L., Green energy tax policies: state and federal tax incentives for renewable energy and energy efficiency. Natural Resources \& Environment, 25(4), pp. 12-14, 2011.

[19] Markova, H., Tax Laws of the Czech Republic 2011, Grada Publishing: Praha, pp. 215-228, 2011.

[20] Full text of Act No. 775 Social Insurance. Sagit: Ostrava, 2010.

[21] Cerníková, M. \& a Pur, D, Management of Environmental Activities of Enterprises, VÚTS, a.s.: Liberec, pp. 12-15, 2011. 